\title{
Electronic Commerce as a Sustainable Business
}

\author{
Mohammad Reza Nemat Gorgani ${ }^{1}$
}

\begin{abstract}
Environment, societies, and economy are the scope of sustainability in each community. Electronic commerce (e-commerce) is rapidly developing due to its potential as a green business, democratic partnership and economic opportunity. Iran to date has grappled with a significant decline in economic activity across multiple economic sectors, lasting more than a few months (years?), normally apparent in real gross domestic product (GDP), real income, employment, industrial production, and wholesale-retail sales. In this context, this study's main objective is to demonstrate that e-commerce could be a powerful factor in creating a sustainable future for Iran. Defining Environmental economics and Innovation, competitiveness and eco-efficiency factors by the Delphi method and the Europe 2020 strategy in the National Sustainable Development Committee of Iran, these elements have been evaluated using the Decision Making Trial and Evaluation Laboratory (DEMATEL) technique with regards to Iran's condition. Finally, the study results support the view that although Sustainable Economic and Innovation, competitiveness and eco-efficiency can be impacted by e-commerce in Iran, it stands to have the greatest impact on environmental economics. In addition the adoption of e-commerce would be both operationally and strategically viable for Iran's society.
\end{abstract}

Keywords: Socio-Economic Development, Green economics, Economic Sustainability

\section{Introduction:}

In every business and non-profit activities, economic and social aspects will be hidden side of it; terminologically, economy is a "science of optimal allotment of scarce resources" (Nazari, 2011)and socially, is a culture and partnership of native people. Sustainability consists of these terms and its impact on business activity is becoming more apparent. Sustainability is a normative notion about the way how humans should act towards nature, and how they are responsible towards one another and future generations (Clark,, 2007). Increasing effects of environmental change are making businesses play a role in sustainability, illustrated well by the concept of the triple bottom line.

Nowadays Corporate Social Responsibly (CSR), environmental impacts, and green economy not only reduce the negative impact on the environment and society, but they can also increase company's competitive advantage. Nicolas Stern, the British economist also points out: "Let's find a green developing path, walk out ofthis economic depression, this road not only can make our earth free from ecological risks but also promote the new investment, so as to create a safer and cleaner, more attractive 
economy". The concept of "Green Economy" was first proposed by Pierre, the British economist. In the green economy, accommodation is made for the capacity of natural resources and other environmental constraints.

It is therefore an economic model that regards as goals the well-being of men, economic and environmental harmony, and continuous development. It is people-oriented, aiming for improvement of standards of living, harmonious coexistence of people and nature, and the facilitation of fair social systems (Xiaowei \& et al, 2011).

Socio-economic development is a core element of the Sustainable Development Strategy. The strategy sets out the objective of promoting a prosperous, innovative, knowledgerich, competitive and eco-efficient economy, which provides high living standards and full and high-quality employment throughout the society.

Green economy impacts the Socio-economic development of countries, this concept is often cited in contemporary literature, but approaches to its evaluation are scarce; Certain researchers have elaborated on a development index that presents a more general concept of wellbeing; one which contains the basis of the HDI with its notions of social and economic progress. Three key areas can be drawn upon for its identification and determination: resources, infrastructure, and the environment(Natoli \& Zuhair, 2011).Over the last few decades, internet connectedness has been introduced as an indicator of socio-economic development and several papers have emphasized its importance(Dobrota, \& et al, 2012). It is significant impacted by e-commerce, the establishment of such strategic infrastructure is considered critical for developing countries where the marginal impact of improved network communications can be very high, leading to improved economic productivity, governance, education, health and quality of life, particularly in rural areas(Madon, 2000).

E-commerce as a green business refers to the use of electronic means and technology to conduct commerce (the sale, purchase, transfer or exchange of product, services and/or information); the delivery of those products, services, or information may occur over or outside of the internet (Manzoor, 2010). Using renewable energy resources, enhancing material recyclability, reducing toxic dispersion are all eco-efficient practices while doing green business(De Simone \& et al, 2000). Consumer environmentalism changed the patterns of competition in the industries and forcing business to redesign products, process and adapt new technology. Ranganathan identified four key elements for environmental performance and four elements for social performance(Ranganathan, 1998).Namely environmental factors are: material use, energy consumption, non-product output and pollutant release, and as social factors are: employment, community relations, ethical sourcing and social impact.

The potential positive environmental impacts of e-commerce have been summarized as “three D's" in the current economy: Dematerialization reduces material consumption by shifting books to bytes, compact disks to MP3s, check books to clicks and so on; Decarbonization reduces greenhouse gas emissions and puts the goals of the Kyoto protocol within reach; Demobilization reduces the need for transportation and its associated costs and consequences (Tiwari \& Singh, 2011). This strategy can lead our society to sustainability and our business model to a green economy; is one that results in improved human well-being and social equity, while significantly reducing environmental risks and ecological scarcities (Bassi \& Sheng, 2012).This notion is defined as ecoinnovation. The goal of eco-innovation is to systematically align and implement this 
strategy throughout the supply chain, from new product and service development to consumption (Jones \& et al, 2008). Eco-innovation as the production, assimilation or exploitation of a product, production process, service or management or business methods that is novel to the organization (developing or adopting it) and which results, throughout its life cycle, in a reduction of environmental risk, pollution and other negative impacts of resources use (including energy use) compared to relevant alternatives(Jin \& et al, 2008).Eco- innovation (green innovation) can be classified into three main categories: eco-product innovation, eco-process innovation and green managerial innovation(Sezen \& et al, 2013).E-commerce belongs to the eco-process because it is focusing on data transferring; eco-process implementation involves the improvement of existing production processes or the addition of new processes to reduce environmental impact(Cheng \& et al, 2012).

\section{Materials And Methodology}

This study utilized Decision Making Trial and Evaluation Laboratory (DEMATEL) technique, which was invented in Geneva, Switzerland in 1971 by the Mattel Memorial Institute to assess complex global problems with the aim of strategic planning and achieving solutions to complicated challenges. This subjective approach relies on interviews and questionnaires to take expert opinion into consideration(Gabus AFE, 1973). In this study information was gathered from the members of national committee of Iran Sustainable Development according to their profession. This technique is used extensively to organize variables and a visual framework in determining complex interactions between those variables through the use of graphs. This technique is also for arranging a series of data in a way that the intensity of interdependency and interactions between variables are scored, feedbacks and their significance are found and then nontransferable relations are accepted (Asgharpour, 2004). The procedure is as follows:

1. Variables are proposed based on the Euro 2020 strategy on the GDP, and socioeconomicdevelopment sector. Those variables are then refined and revised based on inquiry of experts (Delphi method) in order to develop a list of context specific variables (in this study, we used variables relevant to Iran's current condition). The analysis of GDP was focused on data from Economic development, Innovation, competitiveness and eco-efficiency; while the analysis of socio-economic developmentused data regardingEmployment.

Next the panel group members analyzed and ranked the variable; in this study the variable were defined and categorized into three classes; e-commerce, socio-economic development, and real GDP per capital (the last two of which are main indicators of sustainable development). E-commerce included all information, products and services purchased or procured through the internet. Socio-economic developmentwas limited to the costs and negative effects of unemployment on society. GDP included all the strategy's objectives to ensure that our business system meet society's economic, social and environmental needs whilst minimizing their undesirable impacts on the economy, society and the environment.

2. Group decision making was employed following the Delphi method (each expert answers a questionnaire, those answers are then compiled and summarized anonymously along with justification or reasoning provided for each answer and the process is 
repeated). In doing so, the expert panel eventually reaches consensus on a decision and develops associations between variables. For this study, experts in ICT, economy, and environmental science from Iran's National Committee of Sustainable Development were consulted.

3. The intensity of final relation between variables is scored using a five point scoring method (scores are from 0 to 4 ).

4. For further analysis of each variable relationship, the final adjusted scoring of step 3 is put in a Table 1.

\begin{tabular}{|c|c|c|c|c|c|c|c|}
\hline & \multicolumn{9}{|c|}{ Table 1: matrix (N) } & e-commerce & $\begin{array}{c}\text { economic } \\
\text { development }\end{array}$ & innovation & competitiveness & eco-efficiency & employment & sum \\
\hline e-commerce & 0 & 4 & 3 & 2 & 2 & 3 & 14 \\
\hline $\begin{array}{c}\text { economic } \\
\text { development }\end{array}$ & 2 & 0 & 3 & 1 & 2 & 4 \\
\hline innovation & 1 & 1 & 0 & 1 & 4 & 3 & 10 \\
\hline competitiveness & 1 & 3 & 3 & 0 & 3 & 3 & 13 \\
\hline eco-efficiency & 1 & 1 & 1 & 1 & 0 & 1 & 5 \\
\hline employment & 1 & 1 & 1 & 1 & 1 & 0 & 5 \\
\hline
\end{tabular}

5. Each array of matrix $\mathrm{N}$ is multiplied by the inversion of maximum row summation (a) to give matrix M, Results of the equation can be seen in Table 2 .

\begin{tabular}{|c|c|c|c|c|c|c|}
\hline \multicolumn{7}{|c|}{ Table 2: matrix 2(M=a $\times \mathrm{N})$} \\
\hline & e-commerce & $\begin{array}{c}\text { economic } \\
\text { development }\end{array}$ & innovation & competitiveness & eco-efficiency & employment \\
\hline $\begin{array}{c}\text { e-commerce } \\
\text { economic } \\
\text { development }\end{array}$ & 0 & 0.286 & 0.214 & 0.143 & 0.143 & 0.214 \\
\hline innovation & 0.071 & 0.071 & 0 & 0.071 & 0.286 & 0.214 \\
\hline competitiveness & 0.071 & 0.214 & 0.214 & 0 & 0.214 & 0.214 \\
\hline eco-efficiency & 0.071 & 0.071 & 0.071 & 0.071 & 0 & 0.071 \\
\hline employment & 0.071 & 0.071 & 0.071 & 0.071 & 0.071 & 0 \\
\hline
\end{tabular}

6. The relative intensity of direct and indirect correlations between components is presented in Table 3.

\begin{tabular}{|c|c|c|c|c|c|c|}
\hline & e-commerce & $\begin{array}{c}\text { economic } \\
\text { development }\end{array}$ & innovation & competitiveness & eco-efficiency & employment \\
\hline e-commerce & 1.220 & 0.540 & 0.529 & 0.333 & 0.519 & 0.637 \\
\hline $\begin{array}{c}\text { economic } \\
\text { development }\end{array}$ & 0.301 & 1.243 & 0.455 & 0.238 & 0.444 & 0.600 \\
\hline innovation & 0.202 & 0.252 & 1.206 & 0.199 & 0.484 & 0.450 \\
\hline competitiveness & 0.259 & 0.439 & 0.477 & 1.180 & 0.529 & 0.573 \\
\hline eco-efficiency & 0.152 & 0.189 & 0.204 & 0.149 & 1.156 & 0.244 \\
\hline employment & 0.152 & 0.189 & 0.204 & 0.149 & 0.223 & 1.178 \\
\hline
\end{tabular}


7. The relative intensity from indirect relationship between variables can be seen in matrix 4.

\begin{tabular}{|c|c|c|c|c|c|c|}
\hline \multicolumn{7}{|c|}{ Table 4: M 2} \\
\hline & e-commerce & $\begin{array}{c}\text { economic } \\
\text { development }\end{array}$ & innovation & competitiveness & eco-efficiency & employment \\
\hline e-commerce & 0.092 & 0.071 & 0.117 & 0.061 & 0.148 & 0.168 \\
\hline $\begin{array}{c}\text { economic } \\
\text { development }\end{array}$ & 0.051 & 0.102 & 0.076 & 0.066 & 0.117 & 0.102 \\
\hline innovation & 0.051 & 0.071 & 0.081 & 0.051 & 0.051 & 0.071 \\
\hline competitiveness & 0.076 & 0.066 & 0.091 & 0.071 & 0.117 & 0.137 \\
\hline eco-efficiency & 0.025 & 0.046 & 0.051 & 0.025 & 0.061 & 0.066 \\
\hline employment & 0.025 & 0.046 & 0.051 & 0.025 & 0.056 & 0.071 \\
\hline \multicolumn{7}{|c|}{ Table 5: matrix $5=(\mathrm{M} 2 \times(\mathrm{I}-\mathrm{M})-1)$} \\
\hline & e-commerce & $\begin{array}{c}\text { economic } \\
\text { development }\end{array}$ & innovation & competitiveness & eco-efficiency & employment \\
\hline e-commerce & 0.221 & 0.254 & 0.316 & 0.190 & 0.377 & 0.423 \\
\hline $\begin{array}{c}\text { economic } \\
\text { development }\end{array}$ & 0.159 & 0.244 & 0.241 & 0.167 & 0.301 & 0.314 \\
\hline innovation & 0.132 & 0.182 & 0.206 & 0.128 & 0.199 & 0.237 \\
\hline competitiveness & 0.188 & 0.225 & 0.266 & 0.181 & 0.316 & 0.360 \\
\hline eco-efficiency & 0.080 & 0.119 & 0.133 & 0.078 & 0.157 & 0.173 \\
\hline employment & 0.080 & 0.119 & 0.133 & 0.078 & 0.152 & 0.178 \\
\hline
\end{tabular}

8 . Hierarchy or structure of components is thus defined. Table 6 shows the structure of direct and indirect relationships between the chosen variables in this study. Each variable is ranked with regard to its influence on the others, and is also ranked based on its susceptibility to influence from the other variables (matrix 5).

\section{Results}

In Table 1, Maximum row summation (R) shows the order of dispatchers (the elements that have strong influence on other elements). Maximum column summation (C) shows the order of receiver elements (those that are strongly influenced). The real rank of each element on final ranking is determined by $(\mathrm{R}-\mathrm{C})$ and $(\mathrm{R}+\mathrm{C})$ columns, such that (R-C) shows that the component is a dispatcher or a receiver. If the value is positive then the component is a dispatcher; if the value is negative, then it is a receiver. The value of $(\mathrm{R}+\mathrm{C})$ shows the sum of intensity of an element, either on influencing or being influenced by other elements.

\section{Discussion}

Based on the results drawn from export evaluations and group decision making (DEMATEL technique), we graphed the impact and significance of e-commerce on the elements of competitiveness, economic development and innovation in Figure 1. This figure clearly shows that competitiveness and economic development are most affected by e-commerce. 
On the other hand, Table 1 implies that given Iran's current state of affairs, ecommerce would have minimal impact on employment rate and its associated factors (e.g. unemployment rate by sex and employment rate by level of education, etc.).

Although there are many reasons for ecommerce's minimal impact on employment in Iran, the existence of a legal vacuum is Iran's most important hindrance. Moreover, businesses are not incentivized to encourage e-commerce usage, and there are no disincentives for not participating (such as a tax discount). Accordingly, although more than half of Iran's population is under the age of 35, with a great desire to engage in ecommerce and the virtual world, Iran's business sector has found little reason to implement practices that favor a green economy. Since the country's IT infrastructure is old and outdated, requiring significant investment in the form of reconstruction and new technology, companies cannot financially afford to handle this problem on their own. Given these obstacles, the approach of ecommerce would not by itself have a noticeable impact on employment in Iran.

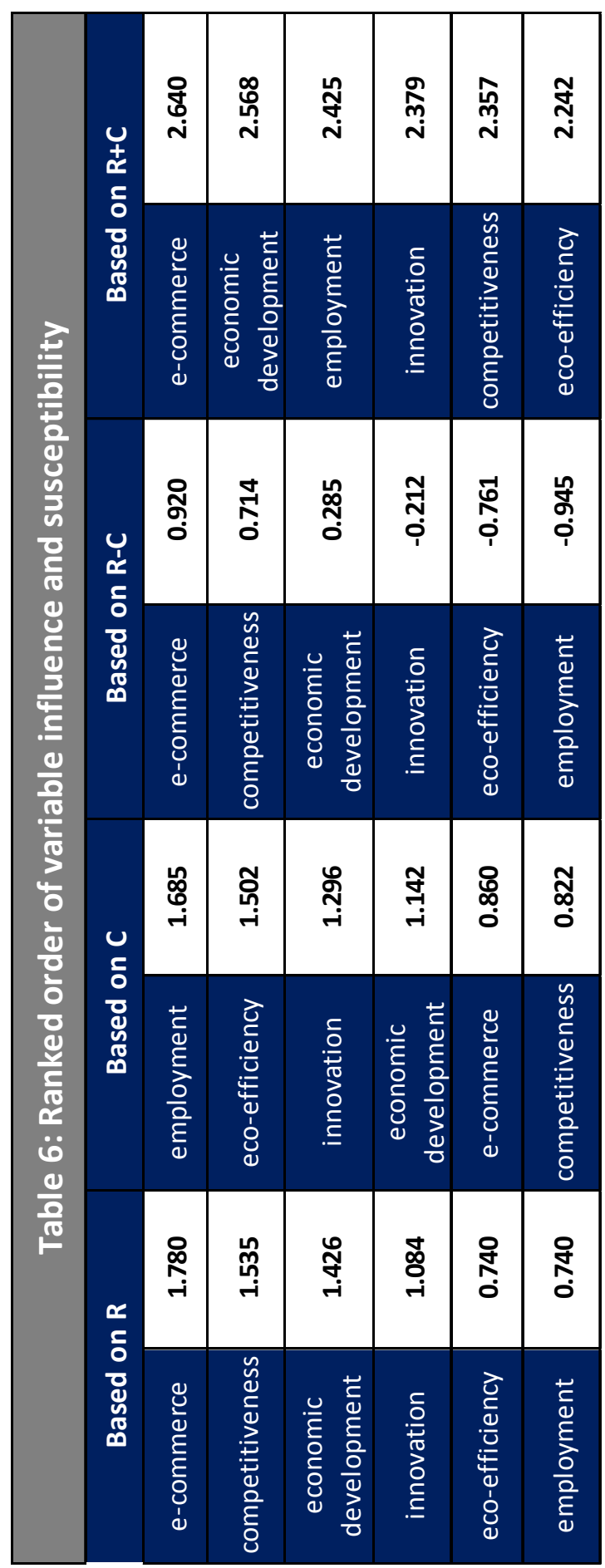




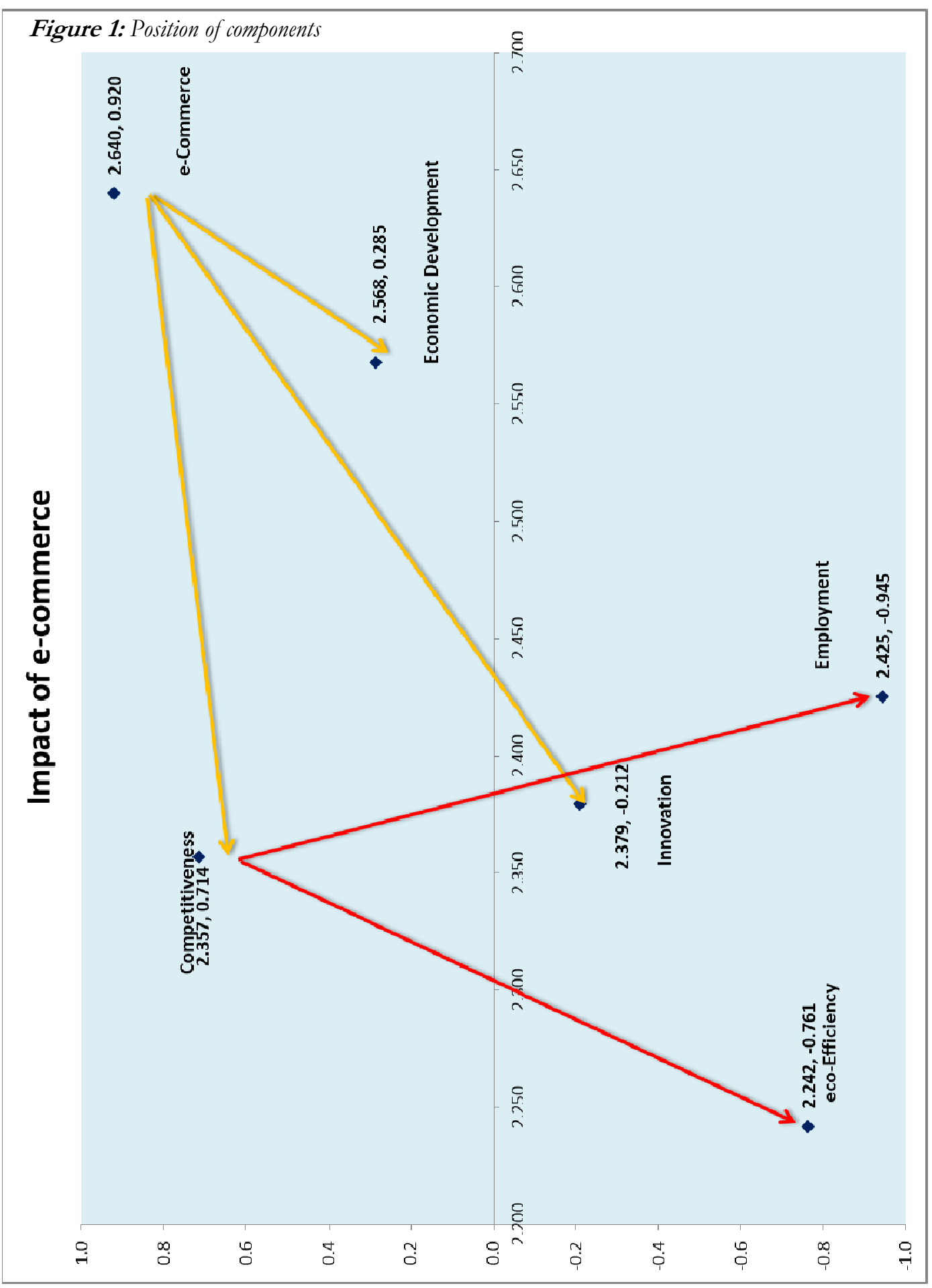




\section{Conclusion}

We propose that the implementation and use of e-commerce will increasereal GDP per capital and encourage sustainable socio-economic development. Our data analysis on the impact of e-commerce on sustainable socio-economic development, real GDP per capital, and employment shows that e-commerce ventures in the Iranian context (barring the lack of a legal system to regulate it) could have a major impact on GDP per capital, with far-reaching positive consequences on competitiveness, economic development and other associated outcomes. It is unfortunate that the experts with whom we consulted predicted e-commerce to have a minimal impact on employment; however, we maintain that development and implementation of e-commerce in Iran would have beneficial effects in terms of economic development, as well as competitiveness and innovation effects.

\section{References:}

Asgharpour, M. (2004). Group decision making and game theory in Operation Research. Tehran: Tehran University Publication.

Bassi , A., \& Sheng , F. (2012). Measuring Progress towards an Inclusive green economy. Nairobi: United Nations Environment programme(UNEP).

Cheng, C., \& et al. (2012). Validation of a proposed instrument for measuring eco-innovation. An implementation perspective, Technovation, 329-344.

Clark,, W. (2007). Sustainability Science: a room of its own. Proceedings of the National Academy of Science, 17371738.

De Simone, L., \& et al. (2000). Eco-Efficiency. The Business Link to Sustainable Development, 56-57.

Dobrota, M., \& et al. (2012). A new perspective on the ICT Development Index. Information Development, $271-280$.

Gabus AFE. (1973). Perceptions of the World Problematique: Communication Procedure Communicating With Those Bearing Collective Responsibility. Geneva: Battle Geneva Research Centre.

Jin, J., \& et al. (2008). Development of product eco-innovation: cases from China,. Emerging and New Approaches to R\&D Management. Ottawa: Research and Development Management (RADMA).

Jones, P., \& et al. (2008). Marketing and Sustainability. Marketing Intelligence and Planning, 123-130.

Madon, S. (2000). The Internet and socioeconomic development:exploring the interaction. Information Technology \& People, 85-101.

Manzoor, A. (2010). E-commerce: An introduction. saarbrucken: Lap Lambert academic publishing.

Natoli, R., \& Zuhair, S. (2011). Measuring progress: a comparison of the GDP, HDI, GS and the RIE. Social Indicators Research, 33-56.

Nazari, M. (2011). Principles of Economics. Tehran: Negah-e-Danesh.

Ranganathan, J. (1998). Sustainability rulers: Measuring corporate environmental and social performance. Sustainability Enterprise Perspective, 1-11.

Sezen, B., \& et al. (2013). Effects of green manufacturing and eco-innovation on sustainability performance. Social and Behavioral Sciences, $154-163$.

Tiwari, S., \& Singh, P. (2011). Environmental Impacts of E-Commerce. International Conference on Environment Science and Engineering (pp. 202-207). Singapore: IACSIT Press.

Tubran, E., King, D., \& et al. (2011). Introduction to Electronic Commerce, Third Edition. Pearson.

Xiaowei, J., \& et al. (2011). New Approaches to the Green Economy of China in the Multiple Crises. Energy Procedia, 1365-1370. 